\title{
Tabanid Infestation of Cattle and Its Implications for Public Health
}

\author{
Mehmet Acı̈̈ ${ }^{1}$ \\ ${ }^{1}$ Province Directorate of Food, Agriculture and Livestock, Datça, Muğla,
}

Received: 03 September 2018, Accepted 26 November 2018, Published online: 27 December 2018

(C) Ordu University Institute of Health Sciences, Turkey, 2018

\begin{abstract}
Female tabanids are important for public health and veterinary. As bloodsucking pests and vectors of disease agents they give harm to humans. They serve as vectors of such agents as Dermatobia hominis, Loa loa, Tularemi, Bacillus anthrasis, Trypanosoma evansi, Coxiella burunetti, Dirofilaria repens. Cattlemen living here raise their cattle on vineyards and orchards, olive groves, almond groves or uncultivated lands. These animals are tied with a halter and a long strap fixed to the ground. The aim of this study was to investigate tabanids infestation in Datça, Muğla. The study was conducted from April 2018 in Datça district. In this paper the Holstein hybrid cattle, old male cattle, tabanids sucking its blood as well as the diseases caused by tabanids are the subject of the study. The skin integrity on the lateral aspect of distal metacarpus in the left hind limb of the cattle was impaired. Hundreds of tabanids lacerated the skin, and sucked blood, causing hemorrhage in the epidermis. This study revealed that tabanids constitute a threat to animal and public health. We highlight the importance of effective prevention and control measures during periods in which these flies are active. More comprehensive epidemiological studies should be undertaken and national control programs are required to keep the tabanids infestation under control.

Key words: Cattle, public health, tabanids
\end{abstract}

Address for correspondence/reprints:

Mehmet Aciöz

Telephone number: +90 (507) 79594373

E-mail: mehmetacioz@hotmail.com

DOI: $10.19127 / \mathrm{mbsjohs} .456516$

\section{Main text and Results}

Tabanids are ectoparasites which are widely seen in Turkey just as in other parts of the world. They are colloquially known as moth, warble fly or horsefly. In Turkey there are 173 tabanid species of tabanus genius (Girişkin, 2017).

Female tabanids are important for public health and veterinary. As bloodsucking pests and vectors of disease agents they give harm to humans. They serve as vectors of such agents as Dermatobia hominis, Loa loa, Tularemi, Bacillus anthracis, Trypanosoma evansi, Coxiella burunetti, Dirofilaria repens (Taylor and Smith, 1989).

With their piercing-sucking mouthparts tabanids impair the skin integrity of hosts, thereby causing pain. Having anticlotting enzymes in their salivary glands, tabanids feed on the blood of hosts, which wells up. Being large, robust and agile these flies have a body length between 5 and $30 \mathrm{~mm}$. Their 
body parts are head, thorax and abdomen (Bernard, 2003).

Tabanids can be found all over the world except for Antarctica. Their natural habitats are the bush, meadows, forests, scrubs, ponds, lakes and swamp. They are usually found in warm areas. They cannot fly when it is below $13^{\circ} \mathrm{C}$, windy, stormy, rainy and dark. They are active in the daytime (Yücel, 2015).

To complete their life cycle tabanids may require one year while an average lifespan of an adult is one to one and a half month. As for mating the female of the species needs a blood meal before depositing her egg mass. Following the mating process, they lay their eggs at the hottest time of the day on wet sites or vegetation that stands over water. The larval stage usually lasts from 6 to 11 months, although it shows variation across species. Until the arrival of warmer seasons larvae stay inactive 5 to $10 \mathrm{~cm}$. below the soil surface. Larvae mature and pupate when spring arrives. The pupal stage can last one month depending on climate conditions. After that period pupae become adults (Wall and Shearer, 1997).

Tabanids are given as vectors of blood-dwelling pathogens of several human diseases (e.g., tularemia, anaplasmosis, filariosis, anthrax, Lyme disease), and they induce allergic reactions in the host when sucking blood (Hornok et al., 2007).

This study deals with tabanids as nuisance pests of cattle as well as their importance for public health.

\section{Methods}

The study area is Datca, a district of Mugla Province in the Aegean region. Datca peninsula is at the meeting point of the Aegean and the Mediterranean, lying approximately between $36.60^{\circ}-36.75^{\circ}$ N. latitude and $27.40^{\circ}$ $28^{\circ} \mathrm{E}$.longitude. Its shoreline length is $235 \mathrm{~km}$. It has 52 bays of different sizes. The peninsula, which is between Gökova and Hisarönü bays, has a Mediterranean climate, characterized by rainy winters and dry summers. The locals depend mostly upon tourism for their livelihood (Anonymous, 2018).

This study was carried out in Datca in April 2018. Cattlemen living here raise their cattle on vineyards and orchards, olive groves, almond groves or uncultivated lands. These animals are tied with a halter and a long strap fixed to the ground. In the pastures they consume the required amount of dry matter on a daily basis. In this paper the Holstein hybrid cattle, an old male cattle, tabanids sucking its blood as well as the diseases caused by tabanids are the subject of the study.

\section{Results}

It was observed that hundreds of flies were flying around the cattle. Cattle's restlessness and not grazing were noted. At the clinical examination of the animal, a heavy infestation with tabanids was detected especially in it slower-extremity. The skin integrity on the lateral aspect of distal metacarpus in the left hind limb of the cattle was impaired. Hundreds of tabanids lacerated the skin, and sucked blood, causing hemorrhage in the epidermis (Fig.1).

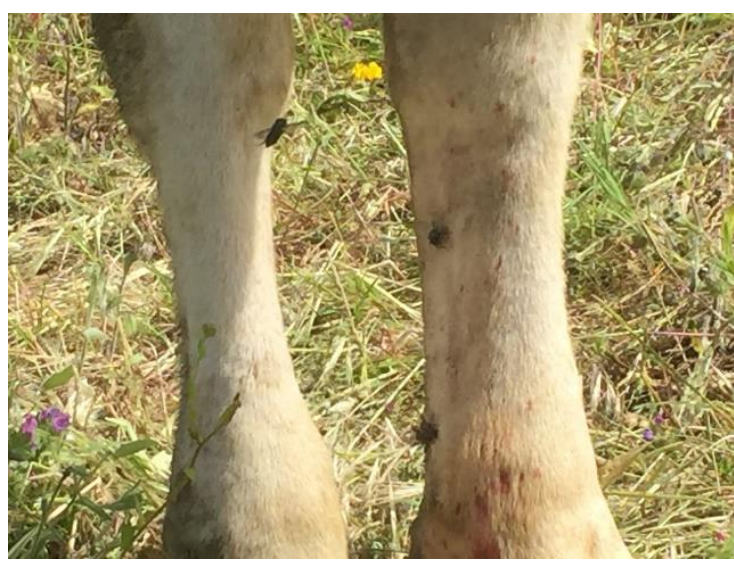

Figure 1. Tabanids feeding on a cattle's leg. Previous feeding lesions can also be seen.

\section{Discussion and Conclusion}

Tabanids are mechanical and/or biological vectors of 27 infections, posing a real risk to human and animal health (Table 1).

The study was conducted in Datça, Mugla Province, which has major tourist destinations. In 2007 alone Mugla Province received 2.089.503 million tourists, 7 percent of the average number of international tourists to Turkey (Anonymous, 2018). With its $235 \mathrm{~km}$. shoreline and 52 bays Datça has a great significance for Mugla Province. Datca receives a huge influx of tourists especially between May and October. As cattle raising takes place near the seaside, a heavy infestation with tabanids affects public health in the town as well. Since many tourists from different countries come to this holiday destination, it is also probable that people 
whosuffer from Filaria, Loiasis and Q fever travel to here.

In general tabanids suck blood every 5 minutes and change hosts very frequently. As a result, they play a significant role in the transmission of infectious agents (Hornok et al., 2007). We argue that this may pose a great risk to the health of local residents as well as tourists in Datca.

Table 1. Tabanids of infections that infect humans and other animals

\begin{tabular}{|c|c|c|}
\hline No & Disease agent & Vectoring \\
\hline 1 & Besnoita besnoiti & mechanical \\
\hline 2 & (Surra) & mechanical \\
\hline 3 & Trypanosoma vivax & mechanical \\
\hline 4 & Trypanosoma congolense & mechanical \\
\hline 5 & Trypanosoma equinum & $\begin{array}{l}\text { mechanical } \\
\text { mechanical }\end{array}$ \\
\hline 6 & Haemoproteus metchnikovi & +biological \\
\hline 7 & Loiasis & biological \\
\hline 8 & Elaeophora schneideri & biological \\
\hline 9 & Dirofilaria repens & biological \\
\hline 10 & Dirofilaria. roemeri & biological \\
\hline 11 & $\begin{array}{l}\text { Clostiridium perfringens } \\
\text { Fusobacterium }\end{array}$ & mechanical \\
\hline 12 & necrophorum & mechanical \\
\hline 13 & Coxiella burnetii (Q fever) & mechanical \\
\hline 14 & Anaplasma marginale & mechanical \\
\hline 15 & $\begin{array}{l}\text { Francisella tularensis } \\
\text { (Tularemi) } \\
\text { Bacillus anthracis }\end{array}$ & mechanical \\
\hline 16 & (Anthrax) & mechanical \\
\hline 17 & Borrelia burgdorferi & mechanical \\
\hline 18 & Influenza & mechanical \\
\hline 19 & Bovine Viral Diarrhoea & mechanical \\
\hline 20 & Equine Infectious Anemia & mechanical \\
\hline 21 & Enzootic bovine leucosis & mechanical \\
\hline 22 & Rinderpest & mechanical \\
\hline 23 & Tick-Borne Encephalitis & mechanical \\
\hline 24 & West Nile Virus Infection & mechanical \\
\hline 25 & Swine Fever & mechanical \\
\hline 26 & California encephalitis & mechanical \\
\hline 27 & Dermatobia hominis & mechanical \\
\hline
\end{tabular}

and lose weight. According to the findings of a study conducted during a grazing season in the USA, a cattle suffered from a weight loss of $90 \mathrm{~kg}$. because of serious irritation caused by tabanids (Davis 1979). Furthermore, in another study it was reported that tabanids led to a decrease in the milk production of dairy cattle (Lehane 2005). The present study showed that being irritated by tabanids, most of the animals cannot eat enough feed.

A study found the amount of blood which tabanids suck at every bite is $0.168 \mathrm{ml}$ (Tashiro and Schwardt, 1953). The present study reported attacks by tabanids on the cattle for bloodsucking. This resulted in open wounds on the skin, which in turn attracted myiatic flies as well as made the cattle susceptible to severe infection with secondary bacterial agents.

In conclusion, tabanids constitute a threat to animal and public health. We highlight the importance of effective prevention and control measures during periods in which these flies are active. More comprehensive epidemiological studies should be undertaken and national control programs are requiredto keep the tabanids infestation under control.

\section{Acknowledgements}

We would like to thank Associate Professor A. Onur Girisgin (Uludag University, Faculty of Veterinary Medicine, Department of Parasitology) for his invaluable help in this study on tabanids.

Peer-review: Externally peer-reviewed.

Author Contributions: Concept - M.A; DesignM.A; Supervision- M.A; Funding- M.A.; MaterialsM.A.; Data Collection/Data Process- M.A; Analyze or Comment- M.A.; Literature Scanning- M.A.; Writer of Paper- M.A.; Critical Review- M.A.

Conflict of Interest: No conflict of interest was declared by the author.

Financial Disclosure: The author declared that this study hasn't received no financial support.

Because of considerable irritation caused by tabanids, bovine animals cannot graze sufficiently 


\section{References}

Anonymous,2018.http://www.muglakulturturizm.g ov.tr/Eklenti/57017,2017-milkapi-aralikpdf.pdf

Barnard DR. Control of Fly-Borne Diseases. Outlooks on Pest Management 2003, 14.5: 222228.

Davis SG. Seasonal and geographical distribution of Tabanus abactor Philip and associated species in the Texas Rolling Plains. A Thesis in Entomology. Texas Tech University. Lubbock, 1979.

Girişkin AO, Tabanidler Vektör lükleri ve Mücadelesi Özbel Y. editör. Vektör Artropodlar ve Mücadelesi, İzmir, Turkey Parazitoloji Derneği Yayın No:25, 2017.

Hornok S, Elek V, de la Fuente J, Naranjo V, Farkas R, Majoros G, Földvári G. First serological and molecular evidence on the endemicity of Anaplasma ovis and A-marginale in Hungary. Vet Microbiol 2007; 122:316-322.

Lehane MJ. The biology of blood-sucking in insects, 2nd edn. Cambridge University Press, Cambridge, 2005.

Tashiro H, Schwardt, HH. "Biological Studies of Horse Flies in New York." J. Econ. Entomol.46:813-22, 1953.

Taylor PD, Smith SM. Activities and physiological states of male andfemale Tabanus sackeni. Med Vet Entomol 1989; 3: 203-12.

Wall R, Shearer D. Veterinary Entomology. UK: Chapman and Hall, 1997.

Yücel ŞY. Tabanidae. Karaer KZ, Dumanlı N, editörler. Arthropodoloji, Ankara: Medisan Yayınevi; 2015. sf. 203-214. 